\title{
PENINGKATAN KOMPETENSI PROFESIONALITAS GURU MELALUI PELATIHAN DESAIN PEMBELAJARAN PETA KONSEP
}

\author{
Yayan Eryk Setiawan*, Syaifuddin \\ Jurusan Pendidikan Matematika, Fakultas Keguruan dan Ilmu Pendidikan, Universitas Islam Malang, Malang, \\ Indonesia \\ * Penulis Korespondensi: yayaneryksetiawan@unisma.ac.id
}

\begin{abstract}
Abstrak
Pemahaman konsep merupakan kemampuan penting yang harus dikuasai oleh siswa. Akan tetapi beberapa guru di MAN Lumajang mengatakan bahwa kesulitan melakukan pembelajaran yang dapat memandu untuk pemahaman konsep. Pembelajaran yang dapat memandu untuk pemahaman konsep a dalah peta konsep. Melalui kegiatan Pengabdian Kepada Masyarakat ini, tim pen gabdi UNISMA akan memberikan pelatihan tentang pembelajaran peta konsep. Hasil pengabdian menunjukkan bahwa guruguru di MAN Lumajang sudah mampu memahami pembelajaran peta konsep yang dapat memandu untuk pemahaman konsep siswa dengan baik dan dapat mengimplementasikan di MAN Lumajang. Respon guru-guru juga sangat positif terhadap pelatihan ini dengan menunjukkan antusias saat melakukkan praktik kerja mandiri dan presentasi.
\end{abstract}

Kata kunci: Pembelajaran Peta Konsep; Pela than; Kompetensi Profesional Guru.

\begin{abstract}
Understanding concepts is an important ability that must be mastered by students. However, some teachers at MANLumajang said that difficulties in learning can guide them to understanding concepts. Learning that can guide to understanding concepts is concept maps. Through this Community Service activity, the UNISMA service team will provide training onlearning of concept maps. The results of the training show that the teachers at MANLumajang have been able to understand the learning of concept maps that can guide students to understand the concepts of students well and can implement at MAN Lumajang. The responses of the teachers were also very positive towards this training by showing enthusiasm when doing independent work practices and presentations.
\end{abstract}

Keywords: Learning of Concept Map; Training; Professional Competence of Teachers.

\section{PENDAHULUAN}

Penca paian kompetensi-kompetensi oleh siswa dalam setiap pembelajaran di kelas tidak lepas dari tugas profesionalitas guru. Tugas profesionalitas guru yaitu penguasaan materi secara luas dan mendalam serta pembelajaran materi yang mudah ditangkap dan dipahami oleh siswa. Profesionalitas guru akan memengaruhi pembelajaran dan selanjutnya pembelajaran akan memengaruhi kompetensikompetensi yang dicapai oleh siswa (Setia wan, 2015). Oleh sebab itu setiap guru dituntut untuk mengembangkan kompetensi profesionalitas guru, dan juga mengembangkan kompetensi-kompetensi guru la innya, yaitu kompetensi pedagogik, kepribadian, dan sosial (Undang-Undang Republik Indonesia Nomor 14 Tahun 2005 Tentang Guru dan Dosen, 2005).

Pengembangan kompetensi profesional seorang guru dapat dilakukan dengan melanjutkan studi ke jenjang yang lebih tinggi, mengikutiberbagai kegia tan pelatihan atau workshop, belajar secara mandiri, atau belajar melalui diskusi kelompok guru (misalnya Musyawarah
Guru Mata Pelajaran atau lebih dikenal dengan istilah MGMP). Untuk mengetahui bagaimana guru-guru mengembangkan keempat kompetensi tersebut, maka penga bdi mela kukan wa wancara dengan wakil kepala bagian kurikulum di Madrasah Aliyah Negeri (MAN) Lumajang. Hasil wa wancara diperoleh bahwa guru-guru ja rang mengikuti pelatihan-pelatihan, kecuali pelatihan yang diadakan oleh pemerintah. Selain itu, untuk belajar seca ra mandiri para guru disibukkan dengan kegiatan a dministrasi dan kegiatan masing-masing guru. Lebih lanjut, wakil kepala bagian kurikulum mengatakan bahwa sangat dibutuhkan a danya pelatihan untuk guruguru di MANLumajang.

Selanjutnya, pengabdi bertanya kepada 2 orang guru mata pelajaran Matematika di MAN Lumajang tentang kesulitan apa yang dialami saat pembelajaran matematika di kelas? salah satu guru menjawab bahwa masih kesulitan melakukan pembelajaran yang dapat memandu untuk memahami konsep. Guru yang lain menjawab bahwa kurangnya pengetahuan tentang metode yang disenangi oleh siswa dalam penyampaian 
suatu konsep ke siswa, sehingga dalam pembelajarannya guru cenderung ceramah. Dari dua orang guru ini diperoleh bahwa sa lah satu permasalahan di MANLumajang a dalah kurangnyapengetahuan guru tentang metode pembelajaran yang dapat memandu untuk memahamikonsep.

Permasalahan kurangnya pengetahuan guru tentang metode untuk membelajarkan suatu konsep akan berdampak pada rendahnya pemahaman konsep siswa. Hasil penelitian Setiawan (2020b) menunjukkan bahwa dari 24 siswa SMA diperoleh $67 \%$ mengalami kesalahan konsep da lam mendefinisikan akar kuadrat dan 70\% mengalami kesalahan konsep dalam mendefinisikan limas segiempat. Kesalahan konsep ini disebabkan siswa tidak mendapatkan pembelajaran tentang definisi dan hubungan sebab akibat yang merupakan dasar pembentukan suatu konsep (Setiawan, 2020b). Hasil penelitian Setiawan (2020a) juga menunjukkan bahwa siswa yang belum mampu melakukan pembuktian memiliki pemahaman matematis yang salah. Ja di, sangat penting bagi seorang guru untuk mengetahui metode-metode yang dapat diguna kan dalam membelajarkan suatu konsep kepada siswa. Karena hal ini akan berdampak pada penguasaan materi pelajaran oleh siswa (Setiawan \& Mustangin, 2020), serta berdampak pada cara yang digunakan oleh siswa da lam menyelesaikan soal ujian (Setiawan, dkk, 2020).

Solusi yang ditawarkan oleh pengabdi untuk mengatasi masalah kurangnya pengetahuan tentang metode untuk membelajarkan suatu konsep adalah dengan memberikan pelatihan kepada guru-guru MAN Lumajang tentang desain pembelajaran peta konsep. Ala san pengabdi memilih pembelajaran peta konsep dika renakan peta konsep memiliki keunggulan, ya itu: peta konsep berfungsi sebagai pemandu dan tangga (scaffolding) dalam pembelajaran, peta konsep dapat mengembangkan pemahaman konsep siswa, serta peta konsep dapat mengembangkan kompetensi-kompetensi siswa, terutama kompetensi kognitif siswa (Setiawan, 2019b). Hasil penelitian Marulcu, dkk (2013) menunjukkan bahwa peta konsep mempenganuhi kinerja siswa dalambelajar secara signifikan.

Hasil survey terhadap kebutuhan untuk diadakannya pelatihan tentang desain pembelajaran peta konsep menunjukkan bahwa dari 40 guru MAN Lumajang terdapat $95 \%$ guru tidak mengetahui tentang pembelajaran peta konsep. Semua guru mengatakan bahwa pemahaman konsep sangat penting dan butuh untuk dilakukan pelatihan tentang desain pembelajaran peta konsep, karena pelatihan desain pembelajaran peta konsep belum pernah dilakukan di MAN Lumajang.

Selanjutnya, MAN Lumajang ini dijadikan sebagai mitra pengabdian ini. MAN Lumajang merupakan sekolah menengah atas yang terletak di Kabupaten Lumajang Provinsi Jawa Timur. MAN Lumajang merupakan satu-satunya sekolah Madrasah Aliyah yang berstatus negeri di kabupaten Lumajang. MAN
Lumajang telah menerapkan kurikulum 2013 yang berbasis pada pencapaian kompetensi. Dimana kompetensi merupakan pengetahuan a tau kemampuan yang harus dicapai oleh siswa yang terdiri dari kompetensi kognitif yang berupa pengetahuan dan kompetensi afektif yang berupa sikap. Kompetensi kognitif ini akan sulit tercapai, jika guru-guru memiliki permasalahan yang berupa kurangnya pengetahuan tentang metode untuk membelajarkan suatu konsep. Apabila masalah initidak diatasi, maka akanberdampak pada rendahnya pemahaman konsep siswa yang selanjutnya dapat berakibat pada penurunan prestasi siswa.

Solusi yang ditawarkan pengabdi adalah pelatihan desain pembelajaran peta konsep. Solusi pelatihan desa in pembelajaran peta konsep ini dapat digunakan seba gai metode untuk membelajarkan suatu konsep, selain itu pelatihan ini dibutuhkan oleh guru-guru MAN Lumajang da n belum a da pelatihan sebelumnya tentang desa in pembelajaran peta konsep. Tujuan utama dari pengabdian ini adalah membekali guru-guru tentang cara mendesain pembelajaran menggunakan peta konsep den gan tujuan untuk meningkatkan pemahaman konsep siswa terhadap materi y ang diberikan.

\section{BAHAN DAN METODE}

Berdasarkan permasalahan mitra, maka solusi yang akan dilakukan dalam kegiatan pengabdian kepada masyarakat di MAN Lumajang a dalah berupa pelatihan guru. Pelatihan ini bertujuan untuk memberikan pengetahuan kepada guru-guru di MAN Lumajang tentang desain pembelajaran peta konsep yang terdiri dari: pembuatan peta konsep, pelaksanaan pembelajaran peta konsep, dan penilaian peta konsep. Pelatihan ini terdiri dari tiga tahap yang da pat dilihat dalam Gambar 1 .

Kegiatan pertama adalah kegia tan pemaparan materi oleh pengabdi. Materi pelatihan yang a kan disampaikan antara lain: (1) Tinjauan awal peta konsep, (2) pentingnya peta konsep, (3) pembelajaran peta konsep yang meliputi cara mendesain pembelajaran peta konsep, cara melaksanakan pembelajaran peta konsep, dan penilaian menggunakan peta konsep. Setelah selesai pemaparan materi, guru-guru diberikan waktu untuk tanya jawab. Kegiatan pemaparan materi dan tanya ja wab ini berlangsung sela ma 1,5 jam.

Setelah pemaparan materi dan tanya jawab selesai, guru-guru melanjutkan kegiatan kedua, yaitu praktik kerja individu dan presentasi. Guru-guru diminta untuk berdiskusi dengan rekan di sampingnya. Dalam kegiatan diskusi ini, pengabdi melakukan pembimbingan terhadap guru-guru dalam mendesain pembelajaran peta konsep yang terdiri dari desain peta konsep dan metode pembelajaran menggunakan peta konsep. Setelah melakukan diskusi dan berhasil mendesain pembelajaran peta konsep, maka perwakilan guru diminta untuk mempresentasikan hasil desain pembelajaran peta konsep. Kegiatan diskusi dan presentasi iniberlangsung sela ma 4 ja m. 


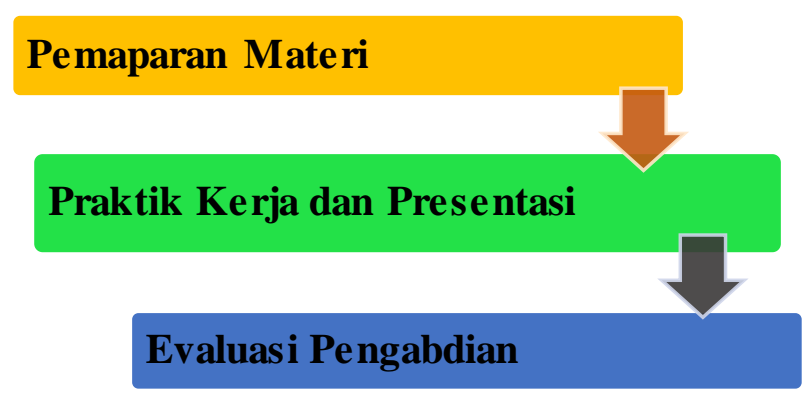

Gambar 1. Tahapan Pelaksanaan Pelatihan.

Di akhir pelatihan diberikan instrumen evaluasi pengabdian yang berupa angket. Isi angket memuat 4 pokok kegiatan yang dievaluasi, yaitu (1) isi ma teri, (2) pemaparan materi, (3) diskusi/tanya jawab, dan (4) praktik kerja in dividu. Hasil angket evaluasi pengabdian dianalisis secara kuantitatif dengan menggunakan pilihan: sangat tidak setuju (STS), tidak setuju (TS), netral (N), setuju (S), sangat setuju (SS). Masingmasing pilihan diberi skor 1,2, 3, 4, 5. Skor darimasingmasing guru diperoleh dengan menggunakan rumus:

$$
\text { Skor }=\frac{\text { Skor yang diperoleh }}{\text { Skor maksimum }} \times 100
$$

Setela h ditentukan skor dari masing-masing guru, maka berikutnya ada lah menentukan ra ta -rata kelas (yaitu skor yang diperoleh semua guru) dan menentukan standar deviasinya. Da ri rata-rata kelas $(\bar{x})$ dan standar deviasi $(S D)$ ditentukan kategori respon guru terhadap pela tihan (lihat Tabel 1) dengan skala Likert (Gufron \& Sutama, 2011).

Tabel 1. Kategori Respon Guru.

\begin{tabular}{cl}
\hline \multicolumn{1}{c}{ Skor } & \multicolumn{1}{c}{ Kategori } \\
\hline$x \geq \bar{x}+1 . S D$ & Sangatbaik \\
$\bar{x}+1 . S D \geq x>\bar{x}$ & Baik \\
$\bar{x}>x \geq \bar{x}-1 . S D$ & Kurang \\
$x<\bar{x}-1 . S D$ & SangatKurang \\
\hline
\end{tabular}

Dari skor yang diperoleh a kan diinterpretasikan secara kualitatif untuk menjelaskan makna dari skor yang diperoleh.

\section{HASIL DAN PEMBAHASAN}

Program Pengabdian Kepada Masyarakat (PKM) yang dilakukan dalam kegiatan ini merupakan pelatihan desain pembelajaran peta konsep. Pelatihan desain pembelajaran peta konsep ini dilaksanakan tanggal 15 Desember 2019 di MAN Lumajang. PKM ini diikuti oleh 40 guru MAN Lumajang dari berbagai bidang studi. Hasil pengabdian kepada masyarakat di MAN Lumajang akan dipaparkan sesuai dengan tahapan pela tihan dalam pengabdian ini.

\subsection{Pemaparan Materi}

Kegiatan pertama adalah pemaparan materi. Materi yang disampaikan adalah tentang tinjauan a wal peta konsep yaitu sejarah penemuan peta konsep, definisi peta konsep, manfaat penggunaan peta konsep dan pentingnya peta konsep (Setiawan, 2019b). Materi berikutnya yang disampaikan ke guru-gun adalah desain pembelajaran peta konsep yang terdiri dari: pembuatan peta konsep dan pembelajaran menggunakan peta konsep yang terdiri dari dua pembelajaran, yaitu mengisi peta konsep yang kosong dan mengkonstruksi peta konsep (Setia wan, 2019b). Kegiatan pemaparan materi dapat dilihat pada Gambar 2 .

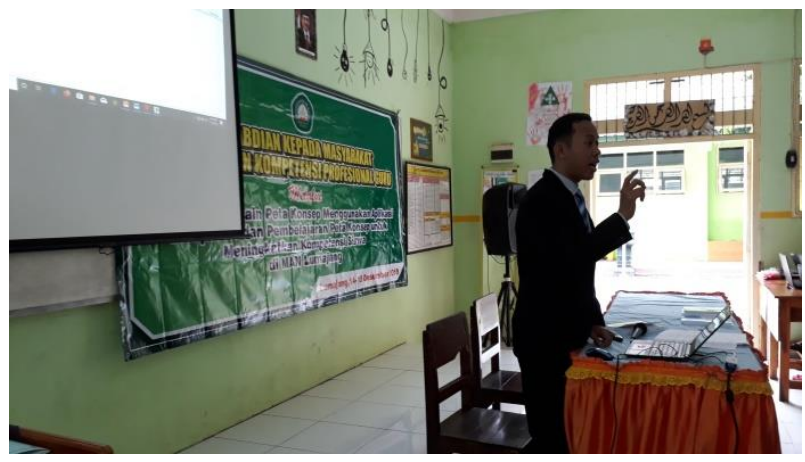

Gambar 2. Pemaparan Materi.

Da lam kegiatan pemaparan materi ini nampaknya guruguru tidak begitu antusias. Hal ini dikarenakan pemaparan materi hanyabersifat teori. Bahkan, ada guru yang memberikan saran, sebaiknya materi secara ringka s saja. Ini artinya bahwa pemberian secara teori dalam pelatihan tidak begitu diperhatikan oleh guruguru. Untuk menyikapi hal ini sesekali, pemateri mengajak guru untuk bercanda, sehingga mencairkan sua sana yang monoton.

Kemudian setelah dilakukan pemaparan materi, maka diberikan kesempatan guru-guru untuk bertanya. Hanya a da tiga guru yang bertanya tentang pentingnya peta konsep dan manfaat peta konsep. Setelah pengabdi menjelaskan kembali tentang pentingnya dan manfaat peta konsep, maka guru menjadi paham. Dalam sesi tanya jawab ini diperlukan a danya umpan balik dari pengabdi untuk mengetahui pemahaman guru-guru, yaitu dengan memberikan pertanyaan balik dan memberikan hadiah bagi guru yang dapat menjawab denganbenar.

\subsection{Praktik Kerja dan Presentasi}

Setelah sesi pemaparan materi dan tanya jawab selesai, ta hapan berikutnya dalampengabdian ini a dalah praktik kerja dan presentasi. Praktik kerja dilakukan secara individu da n boleh didiskusikan dengan rekan yang ada di samping tempat duduk guru. Praktik kerja individu ini terdiri dari desain peta konsep dengan menggunakan a plika si CmapTools (Setiawan, 2019a). Kemudian guru juga diminta untuk mendesain Rencana Pelaksanaan Pembelajaran (RPP) menggunakan peta konsep. Penga bdi bertugas mendampingi guru dalam mendesain peta konsep dan membuat RPP. Kegia tan praktik kerja dapat dilihat dalam Gambar 3. 


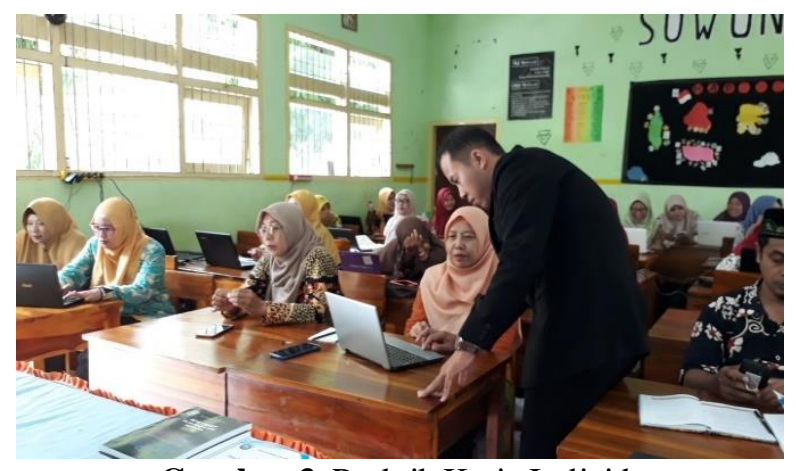

Gambar 3. Praktik Kerja Individu

Guru-guru dalam mengikuti praktik kerja pembuatan peta konsep dan RPP ini sangat a ktif. Guru-guru lebih senang pelatihan dilakukan secara langsung praktik daripada teori terlebih dahulu. Ini artinya, guru-guru di tempat ini lebih suka kegiatan terlebih dahulu baru berpikir. Tetapi secara umum kita menyakini bahwa belajar teori terlebih dahulu, kemudian praktik di lapangan. Berdasarkan pelatihan ini, ternyata guru-guru lebih menyukai praktik di lapangan, kemudian a pabila ada kesulitan, maka sambil mempelajariteori.

Setela h guru-guru berhasil mendesain peta konsep dan RPP kurang lebih selama 4 jam, maka perwakilan dari guru diminta untuk mempresentasikan hasil desain peta konsep dan sekaligus membelajarkan peta konsep di depan rekan-rekan guru lainnya. Guru-guru antusias untuk mempresentasikan hasil desain peta konsep mereka, karena waktu pelaksanaan pengabdian terbatas, maka dipilih 3 guru untuk mempresentasikan hasil desain peta konsep mereka beserta pembelajarannya, yaitu guru mata pelajaran Fisika, Fiqih, dan Matematika. Kegiatan presentasi oleh guru mata pelajaran Fisika dapat dilihat dalam Gambar 4.

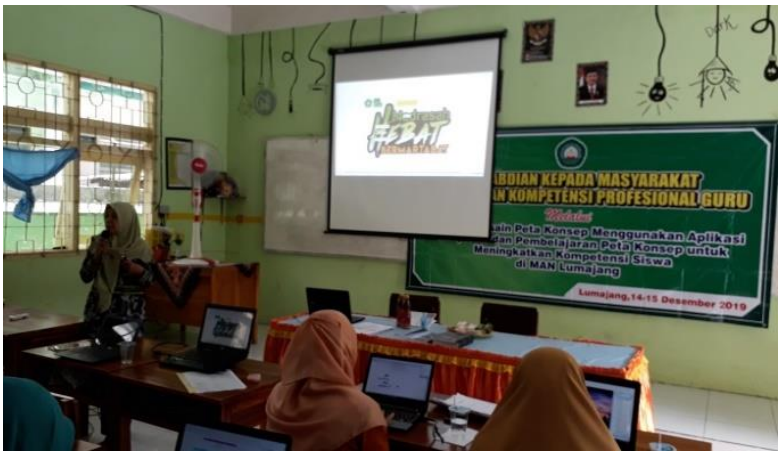

Gambar 4. Presentasi Guru Fisika

Sa at presentasi, guru tersebut merasa mudah dalam memahamkan suatu konsep dengan menggunakan peta konsep, karena alur terbentuknya konsep menjadi lebih jelas dengan adanya peta konsep. Selain itu, guru mengatakan bahwa konsep-konsep lebih mudah diingat oleh siswa, karena pembelajaran peta konsep menghubungkan antar konsep seca ra bermakna, y aitu menghubungkan konsep yang baru dipelajari dengan konsep yang sudah dipelajari.
Setelah presentasi selesai, guru-guru yang la in diminta untuk memberikan tanggapan kepada ketiga guru yang telah mempresentasikan hasil desain peta konsep dan pembelajarannya. Tanggapan guru-guru antara la in: mereka lebih mudah memahami konsep dan merasa cocok dengan pembelajaran peta konsep sebagai pemandu untuk pemahaman konsep. Selain itu, guruguru juga memberi masukan dalam mendesain peta konsep, yaitu: (1) hendaknya dalam peta konsep juga disertakan contoh-contoh. (2) penjelasan terbentuknya konsep perlu diberikan ke siswa, dan (3) definisi setiap konsep perlu disertakan dalam peta konsep.

Dari hasil pengamatan saat praktik kerja individu diperoleh bahwa guru-guru: (1) antusias mendesain peta konsep menggunakan a plikasi CmapTools dari salah satu materi mata pelajaran yang sesuai dengan bidangnya masing-masing, (2) antusias bertanya saat mengalami kesulitan dalam mendesain peta konsep dan RPP, dan (3) antusias untuk mempresentasikan hasil desain peta konsep dan pembelajarannya. Sela in itu, ketika pengabdi bertanya kepada guru-guru, apakah sudah memahami metode pembelajaran menggunakan peta konsep? Guru-guru menjawab bahwa mereka sudah dapat memahami pembelajaran menggunakan peta konsep dan guru-guru mengatakan bahwa dengan menggunakan metode pembelajaran peta konsep akan mempermudah membelajarkan konsep dari suatu materi kepada siswa, ka rena masing-masing konsep terhubung secara bermakna. Guru-guru juga ingin segera menerapkan hasil desain pembelajaran peta konsep mereka di kela s masing-masing.

Pernyataan guru-guru bahwa metode pembelajaran menggunakan peta konsep dapat mempemudah penyampaian suatu materi telah sesuai dengan pendapat Setia wan (2019b) yang mengatakan bahwa peta konsep berfungsi sebagai panduan bagi guru dalam bertindak di kelas untuk mencapai pembelajaran yang memadai Lebih lanjutChiu \& Lin (2012) mengatakan bahwa peta konsep telah banyak diadopsi dalam pendidikan sains dan psikologi kognitif untuk membantu pembelajaran dan penilaian. Halyang sama dikemukakan oleh Dalay (2010) yang berpendapat bahwa peta konsep dapat diguna kan seba gai stra tegi pembelajaran kognitif dan konstruktivis untuk pendidikan orang dewasa. Isabelle (2015) mengatakan bahwa peta konsep telah lama diguna kan sebagai a lat penilaian oleh pendidik untuk mengilustrasikan perkembangan konseptual siswa dari suatu topik seiring waktu dan dapat mengidentifikasi pemahaman seseorang (Chichekian \& Shore, 2013). Jadi melalui pelatihan ini dapat disimpulkan bahwa guru-guru telah memahami cara menggunakan metode pembelajaran peta konsep. Diharapkan kompetensi profesionalitas guru dapat meningkat, terutama dalam membelajarkan materi dikelas.

\subsection{Evaluasi Pengabdian}

Setelah kegiatan praktik dan presentasi selesai, guruguru diminta untuk men gisi a ngket evaluasi pengabdian yang dikembangkan oleh pengabdi sendiri. Dari hasil angket diperoleh ra ta-rata skor pengisia $n$ angket adalah 
88,70 dan standar deviasinya a dalah 6,37. Dengan menggunakan rata-rata dan standar deviasi, maka diperoleh kategori sikap terhadap pelatihan pembelajaran peta konsep yang dapat dilihat dalam Tabel2.

Tabel 2. Ka tegori Respon Guru Terhadap Pelatihan.

\begin{tabular}{cl}
\hline Nilai & \multicolumn{1}{c}{ Kategori } \\
\hline $100 \geq x \geq 95,07$ & Sangatbaik \\
$95,07>x \geq 88,70$ & Baik \\
$88,70>x \geq 82,33$ & Kurang \\
$x<82,33$ & SangatKurang \\
\hline
\end{tabular}

Berdasarkan Tabel 2 diperoleh bahwa dari 27 guru diperoleh 5 guru berada dalam kategori sa ngat baik, 7 guru bera da dalam kategoribaik, 10 guru kurang, dan 5 guru bera da dalam kategori sa ngatkurang.

Guru yang bera da dalam kategori sangat baik memiliki respon sangat positif terhadap pelatihan ini. Kelebihan pela tihan ini menurut 5 guru tersebut adalah: (1) materi sangat bermanfaat, mudah dimengerti, materi a dalahhal yang baru bagi mereka, dan mereka telah bisa mengimplementasikan pembelajaran peta konsep, (2) pemateri mempresentasikan dengan mudah, (3) diskusi membantu pemahaman guru, dan (4) pemateri telah memfasilitasi kerja mandiri secara baik.

Guru yang berada dalamkategori sa ngat kurang a rtinya memiliki respon yang sangat kurang terhadap pelatihan ini. Kekurangan pelatihan ini menurut 5 guru tersebut adalah: (1) Guru mengatakan bahwa materi pelatihan yang berupa peta konsep bukan hal baru, (2) alokasi waktu pen yampaian materi ku rang mencukupi, (3) guru merasa kurang dapat melakukan penilaian, dan (4) pemateri kurang percaya diri.

\section{KESIMPULAN}

Dari hasil pelatihan diperoleh bahwa pengetahuan tentang pembelajaran peta konsep yang dapat memandu untuk memahami konsep sudah dapat dipahami guru dengan baik dan dapat diimplementasikan di MAN Lumajang. Pada saat pemaparan materi diperlukan humor dan umpan balik dari pemateri agar peserta pelatihan lebih bersemangat. Pada sesi tanya jawab, jawaban yang diberikan tidak hanya dari pemateri, tetapi pemateri dapat melemparkan kembali kepada peserta lainnya untuk menguji pemahaman peserta lainnya juga. Pada sesi praktik kerja, pemateri tetap memberikan pendampingan dengan baik dan optimal terha dap guru-guru. Sa ran untuk kegiatan pelatihan ke depan adalah: (1) mencoba menggunakan metode pelatihan praktik-teori-praktik, artinya praktik dilakukan secara langsung dan teori dijela skan saat dibutuhkan waktu praktik dan kemudian praktik kembali, metode ini membuat guru-guru bersemangat. (2) alokasi waktu pelatihan perlu ditambah, (3) pelatihan yang serupa dapat dilakukan di jenjang sekolah dasar dan menengah untuk mengetahui relevansi pembelajaran peta konsep, dan (4) dapat melakukan pelatihan desa in perangkat pembelajaran yang meliputi modul pembelajaran, buku siswa, dan RPP yang berbasis pada peta konsep yang bermanfaat untuk menunjang pembelajaran peta konsep.

\section{UCAPAN TERIMA KASIH}

Terima kasih disampaikan kepada Universitas Islam Malang (UNISMA) yang telah mendanai kegiatan pengabdian kepada masyarakat ini melalui Lembaga Penelitian dan Pengabdian Kepada Masyarakat(LPPM) Universita s Islam Malang. Terima kasih kepada Kepala MAN Lumajang yang telah memberikan kesempatan kepada pengabdi untuk melakukan kegia tan pelatihan ini. Terima kasih kepada waka kurikulum MAN Lumajang yang telah mendukung dan membantu berja lannya proses pengabdian di MAN Lumajang ini.

\section{DAFTAR PUSTAKA}

Chichekian, T., \& Shore, B. M. (2013). Concept Maps Provide a Window onto Preservice Elementary Teachers' Knowledge in the Teaching and Learning of Mathematics. Canadian Journal of Education, 36(3), 47-71.

Chiu, C.-H., \& Lin, C. (2012). Sequential Pattem Analysis: Method and Application in Exploring How Students Develop Concept Maps. TOJET: The Turkish Online Journal of Educational Technology, 11(1), 145-153.

Daley, B. J. (2010). Concept Maps: Practice Applications in Adult Education and Human Resource Development [Perspectives on Practice]. New Horizons in Adult Education and Human Resource Development, 24(2-4), 30-36. Retrieved from http://education.fiu.edu/newhorizons

Gufron, A., \& Sutama. (2011). Evaluasi Pembelajaran Matematika (1 st ed.). Jakarta: Universitas Terbuka.

Marulcu, I., Karakuyu, Y., \& Dogan, M. (2013). Can Elementary Students Gather Information from Concept Maps? International Journal of Environmental \& Science Education, 8, 611625.https://doi.org/10.12973/ijese.2013.223a

Setiawan, Y. E. (2015). Analisis Domain dan Dampak Mathematical Knowledge for Teaching Terhadap Pengajaran. In Hobri (Ed.), Reformasi Pendidikan dalam Memasuki ASEAN Economic Community (AEC) (pp. 1263-1271). Jember. FKIP Universitas Jember.

Setiawan, Y. E. (2019a). Panduan Penggunaan CmapTools untuk Desain Peta Konsep. Lumajang: AL-Mukmin Yes.

Setiawan, Y. E. (2019b). Peta Konsep dalam Pembelajaran Matematika. Lumajang: ALMukmin Yes.

Setiawan, Y. E. (2020a). Ana lisis Kema mpuan Siswa dalam Pembuktian Kesebangunan Dua Segitiga. Al-Khwarizmi: Jurnal Pendidikan Matematika Dan Ilmu Pengetahuan Alam, 8(1), 23-38. https://doi.org/10.24256/jpmipa.v8i1.800

Setiawan, Y. E. (2020b). Analisis Kesalahan Siswa dalam Menilai Kebenaran Suatu Pernyataan. Jurnal Didaktik Matematika, 7(1), 13-31. 
https://doi.org/10.24815/jdm.v7i1.14495

Setiawan, Y.E., \& Mustangin. (2020). Validitas Model Pembelajaran IDEA ( Issue, Discussion, Establish, and Apply) untuk Meningkatkan Pemahaman Konsep. Jurnal Penelitian Pendidikan Dan Pengajaran Matematika, 6(1), 53-60.

Setiawan, Y. E., Purwanto, Parta, I. N., \& Sisworo. (2020). Generalization Strategy of Linear Patterns From Field-Dependent Cognitive Style. Journal on Mathematics Education, 11(1), 7794. http://doi.org/10.22342/jme.11.1.9134.77-94 Undang-Undang Republik Indonesia Nomor 14 Tahun 2005 Tentang Guru dan Dosen (2005). 